\title{
Extreme Hydrological Phenomena in the Esil River Basin: Genesis, General Patterns of Manifestation
}

\author{
Petr Andreevich Plekhanov ${ }^{1}$, Nadira Nusupkyzy Medeu ${ }^{1 *}$ \\ 1 Institute of Geography, 050010, Almaty, Kazakhstan \\ * Corresponding author's e-mail: nadira.medeu@mail.ru
}

\begin{abstract}
The research subject involves dangerous hydrological phenomena (floods) in the Esil River Basin (Akmola and North Kazakhstan regions). The aim set by the authors was to improve the theoretical knowledge about floods and inundations, in order to contribute to solving the general problem of ensuring the safety of the territories in the Esil Water Management Basin (WMB) against harmful effects of water. In Kazakhstan, floods are caused by almost all known causes in the world: in most of the country - spring floods, the high-intensity rainfall. Additionally, there were cases when floods occurred as a result of dam failures (e.g. in the case of the Kyzylagash village in the Almaty region). Annually, the damage caused by floods throughout Kazakhstan amounts to several tens of billions of tenge. The predicted increase in air temperature and precipitation, coupled with the intensive development of farmland river valleys, will undoubtedly lead to the increase in the frequency and destructive power of floods. Therefore, developing a set of measures to prevent and protect against floods constitutes an urgent task. These measures will significantly reduce the expenses for the liquidation of the flood effects. The data on extreme hydrological phenomena (EHP) in the Esil River basin were collected and systematized. The conditions for the formation of high floods on the rivers of the researched region were studied. Various "typical" scenarios of the formation of dangerous and catastrophic floods were presented. The periods of passage of snow-melt floods (high floods) and other regularities of the intra-annual water regime in the Esil river basin were determined.
\end{abstract}

Keywords: inundation, floods, snow-melt floods, flood control, maximum flow, factors and conditions of occurrence of floods, air temperature and precipitation

\section{INTRODUCTION}

Floods in Kazakhstan occur almost annually in many basins and have a significant adverse effect on human settlements, industrial facilities and infrastructure, agriculture, natural landscapes; they are often accompanied by loss of life. In Kazakhstan, the situation is disappointing. On the one hand the average of maximum flow discharges decreased 1.5-3 times (Resources of river flow of Kazakhstan, 2012). By 2006, there were 653 hydrological technical facilities (HTF) in the republic, 268 of which, including 28 large ones, needed major repairs. The average actual wear in water facilities is $60 \%$ (Decree of the Government of the Republic of Kazakhstan "On the concept of prevention and liquidation of natural and man-made emergency situations and improvement of the state management system in this area", 2005; Plekhanov, Rajushkin, 2011). The gravity of the situation is evidenced, for example, by the catastrophe that occurred in March 2010 on the insignificant Kyzylzhar river in the Almaty region. As a result of the dam failures at the spring flood, then 45 people died, over a thousand families suffered, and the total damage was estimated at a minimum of $\$ 100$ million (Plekhanov, Rajushkin, 2011). According to expert estimates of the Emergency Situations Committee of the Ministry of Internal Affairs of the Republic of Kazakhstan, floods rank second after earthquakes in the Disaster Risk Profile of the Republic of Kazakhstan (Plan of preparedness of the Republic of Kazakhstan for natural emergencies, 2015). In some years, huge areas are exposed to floods in the river basins of the Republic, at least 918 
localities with a total population of over 5 million people are affected directly.

The causes of floods in the republic in various regions are heavy and prolonged rains, intense melting of snow cover on the plains, failure of lakes and reservoirs, water surge on large bodies of water, flood ice, ice jams on rivers, etc. (Kusainov, 2015; Warning of an emergency situation during the spring flood period, 2012). One of the ways of floods control in the United States is the water drain. Currently, the USA flood protection policy is based on the National Flood Insurance Program (NFIP): identification and mapping of flood-prone areas; control over the implementation of standards and rules for the use of flood hazard areas; flood insurance (National Flood Policies and Programs in Review, 2007; Shalikovsky, 2009). In 2007, due to the significant damage caused by floods, the European Parliament adopted the "European Union Directive 2007/60 / EU on flood risk assessment and management". Its goal is to reduce the negative effects of floods on the human health, environment, cultural heritage and economic activity through the introduction of flood risk management (Directive 2007/60/EC, 2007; Connelly et al., 2015; Harvey, Hall, Manning, 2014). In Holland, it includes timely warning, prevention and dissemination of information about the nature and risks of floods. Continuous water management in China, in accordance with laws and regulations, flood control work is carried out according to the principle of holistic planning, creating intensive plans and taking into account all flood prevention factors, and it is the main priority of integrated water and land management (Yuldashev, 2010; Xu et al., 2002). India is one of the most flood-prone countries in the world after Bangladesh, and they are fairly common throughout the country (Singh, Kumar, 2017). Historical records indicate the high vulnerability of Northwestern Algeria to floods, where more than 130 floods occurred, some of which were catastrophic (Sardou et al., 2018).

\section{EXPOSURE OF THE ESIL RIVER BASIN TO THE INUNDATION AND FLOODS}

Data on extreme hydrological phenomena (the EHP) in the Esil river basin.

The Esil river basin is located in the central and northern parts of Kazakhstan in the Karaganda region (the headwaters, the Akmola and North Kazakhstan regions (upper and middle flow). Specific, albeit fragmentary data pertaining to the extreme hydrological phenomena from various sources in the Esil river basin have been available only since the 1940s. A fragment of the physiographic map of the Esil river basin is presented in Figure 1.

Targeted registration of the facts of extreme hydrological phenomena (EHP), including the floods in the Esil Basin was first started by the efforts of the Kazakh Hydro-meteorological Service only in the mid-1960s. Since 1992, the facts about dangerous hydrological phenomena have

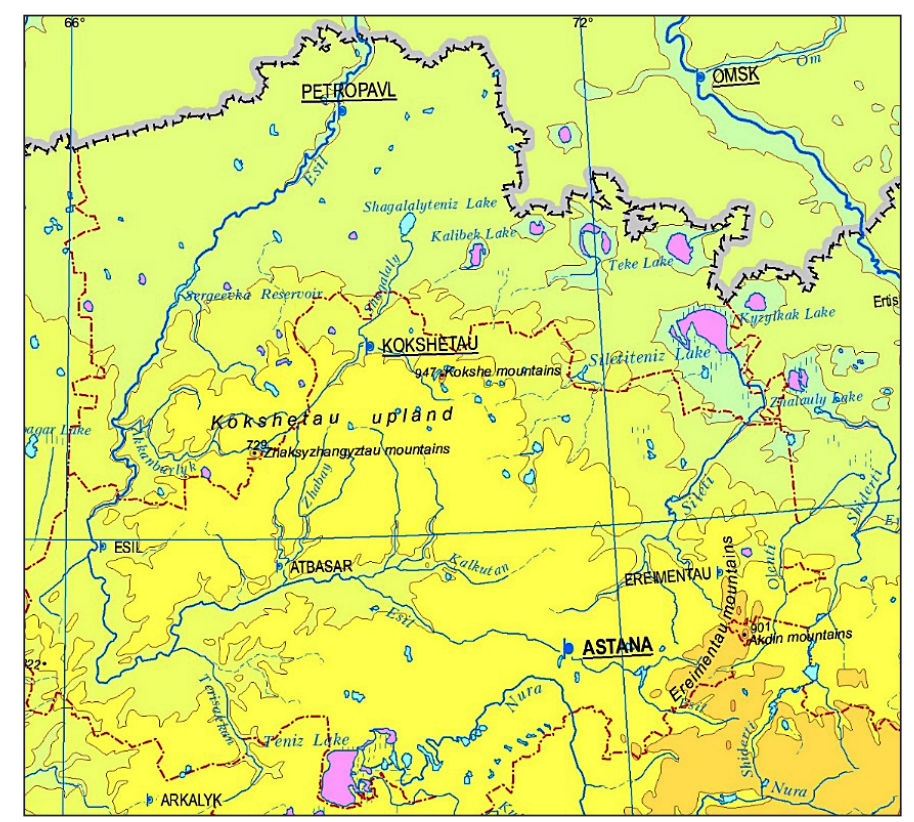

Figure 1. Fragment of the physiographic map of the r. Esil (National Atlas of the Republic of Kazakhstan, 2010) 
also been recorded by the newly created territorial divisions of the State Committee on Emergency Situations in their departmental database. To date, the Esil river basin has collected the information from all known sources on 41 cases of EHP from 1940 to 2018. The EHP data are not unified, and it is impossible to make detailed statistical generalizations about the risks of these phenomena from these data (Plekhanov, Schoenberger, Medeu, 2018). However, some conclusions about the susceptibility of the studied basin to floods and other dangerous hydrological phenomena can still be drawn.

General patterns of EHP:

- the main causes of EHP are:

1) high spring floods -35 cases $(85 \%)$;

2) dam failure of seasonal ponds -3 cases (7\%);

3) increased discharges from reservoirs - 2 cases $(5 \%)$;

4) heavy rainfall during the period of snowmelt - 1 case $(3 \%)$.

- terms of EHP occurrence:

1) March (end) - 3 cases (7\%);

2) April - 35 cases (85\%);

3) May (beginning) - 1 case (3\%);

4) June - (end) - 1 case (3\%).

- consequences of EHP:

1) there were 15 cases of EHP (37\%) with the damage in the form of flooding of residential buildings, agricultural lands, and infrastructure facilities. However, there is no information about the damages in nominal terms.

- long-term characteristics of conditions for the occurrence of EHP:
1) for the study period (1940-2018) in 78 years in the Esil river basin, 33 years were noted with increased water content (or 42\%) and 45 years (or 58\%) with low water content (in accordance with Figure 2).

2) for the period from 1940 to the present, 41 instances of inundation of the area (including floods) during 30 annual periods were documented, including 20 annual periods of inundation in the years with high water content and in 10 periods - in the years with low water content. That means that apparently only twothirds of the recorded floods occurred due to the increased water content.

3 ) the average annual probability (danger) of floods in the Esil river basin is about $53 \%$, that is, floods in the past 8 decades on average occur every two years. Moreover, in the last 4 decades, inundation in the Esil basin has become more frequent and occurs in from 7 to 12 times every decade.

The information presented in Table 1 is undoubtedly incomplete, nevertheless, even in this quantity, it indicates that inundations and floods are one of the most important elements of the hydrological regime of the river of Esil river basin.

\section{STUDY OF THE CONDITIONS OF THE FLOOD FORMATION ON THE RIVERS OF THE REGION UNDER RESEARCH}

The conditions of the spring flood formation should be understood as real time interconnected systems of the existing runoff factors in

Table 1. Information on the susceptibility of the Esil River Basin to inundations and floods in the period from 1941 to 2018

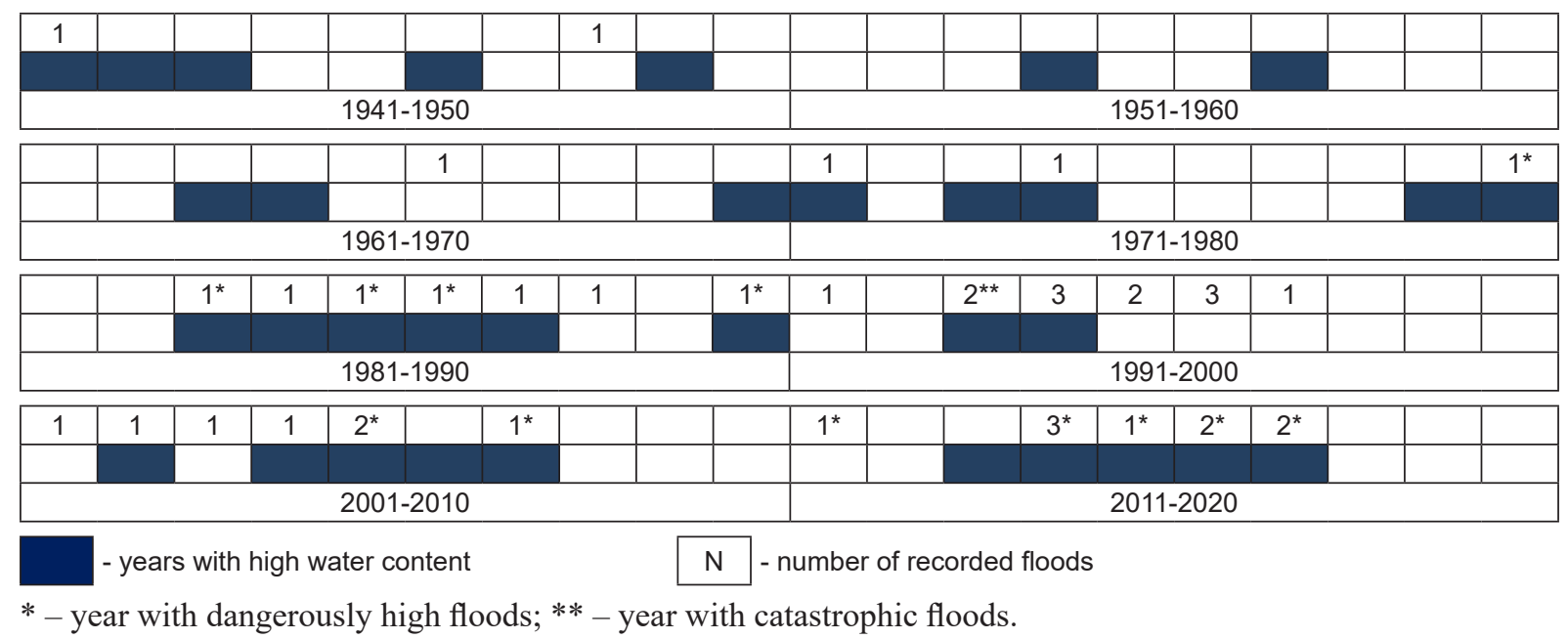


spatial-temporal periods, determining the occurrence and passage of spring flood processes in specific parts of the basin at a specific time. In essence, any spring flood (snow-melt flood) is a unique multifactorial phenomenon with its individually realized complex of cause-consequence relations, ultimately leading to the occurrence of spring flood and, in the worst case - to floods (Plekhanov, Medeu, 2019).

As already noted, the statistics pertaining to the hydrological hazards in the Esil river basin are not abundant. Nevertheless, according to the available data and, based on the practical experience of the RSE "Kazhydromet", various "typical" scenarios for the formation of dangerous and catastrophic spring floods were identified:

- a situation where autumn moistening is above the norm by $70-80 \%$, and winter snow accumulation is within the normal range (for example, 1980)

- a situation where autumn moistening and winter snow accumulation are higher than the norm by more than 30\% (for example, 1983).

- the situation where the autumn moistening is around the norm or slightly higher, the winter snow accumulation is above the norm by $50-70 \%$, and in the spring there is a uniform snowmelt (for example, 1986).
- a situation where autumn moistening and winter snow accumulation are above the norm, then there is a prolonged spring with heavy liquid precipitations during the period of snowmelt (for example, in 1993, when numerous individual catastrophic floods occurred everywhere).

- a situation where autumn moistening and winter snow accumulation are within the normal range, but in the spring period there are a uniform snowmelt and liquid precipitation (for example, 2017).

The periods of flood and other regularities of the intra-annual water regime in the Esil river basin are generally strictly regulated by the climatic and hydrological seasonal features of the region, which are as follows.

For the headwaters of the Esil River (a hydrological post (h/p) Turgenevka):

- October-November is a period of autumnal moisture (autumn low water);

- December-mid March is the period of winter snow accumulation (winter low water);

- the mid-March - early May is a period of high water (spring snowmelt);

- Early May-September is the period of summer-autumn low-water periods (in accordance with Figure 2).
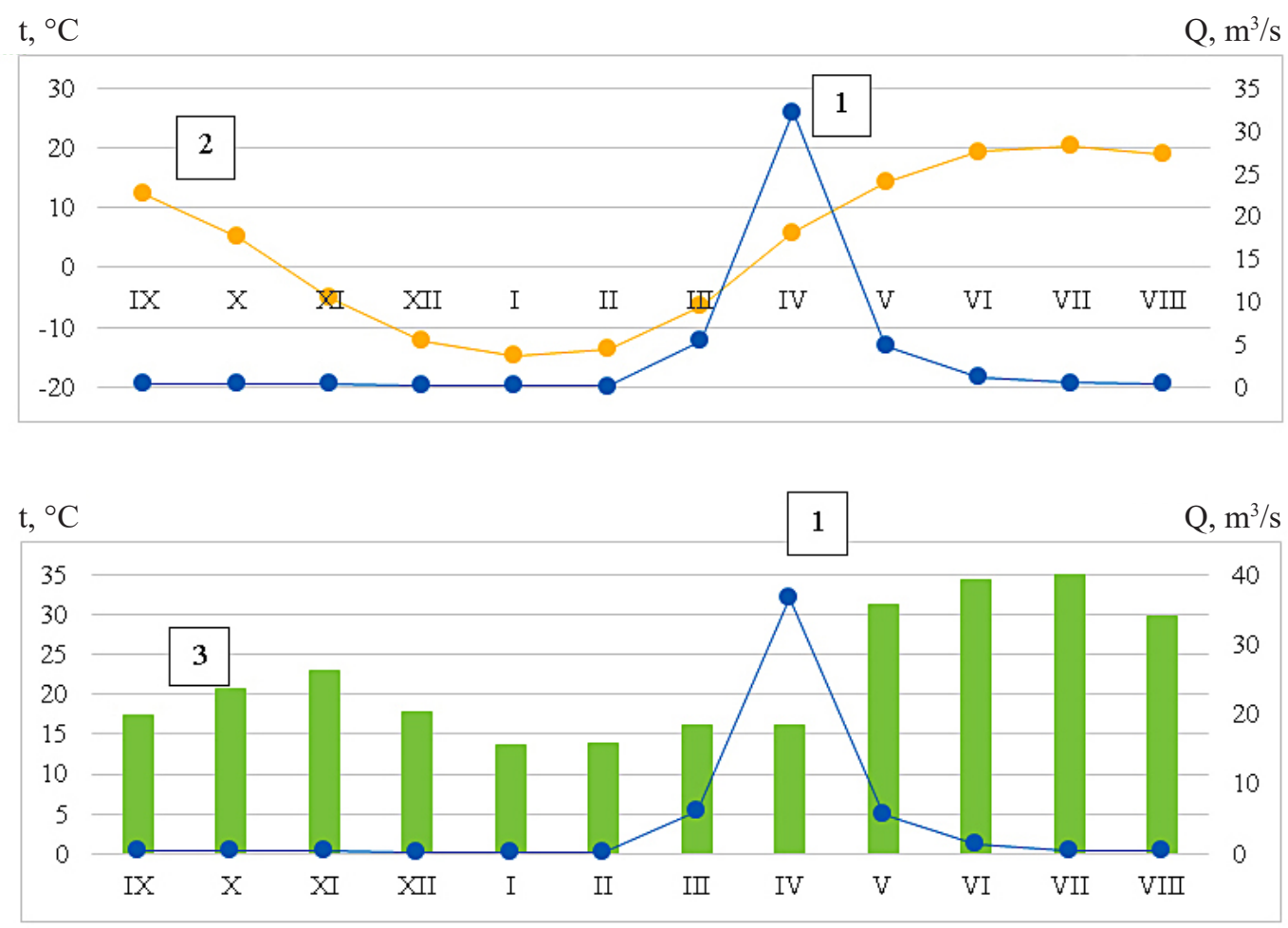

Figure 2. (1) water discharge along the river Esil - the h/p Turgenevka; $(2,3)$ air temperature and precipitation in meteorological station Astana 
For the lower reaches of the river (the $\mathrm{h} / \mathrm{p}$, the Petropavlovsk city) there are shifts:

- October-November - the period of autumnal moisture (autumn low water);

- December-March - the period of winter snow accumulation (winter low water);

- April-June - the period of high water (spring snowmelt);

- July-September - the period of summer-autumn low-water periods (in accordance with Figure 3).

The harmful effects of spring floods in the Esil river basin are largely determined by, among other things, its channel conditions, the characteristic features of which are: small slopes, pronounced meanders, wide, slightly buried river valleys, overgrown with shrubs; bulk bridge crossings blocking the river beds and others (in accordance with Figure 4).

As already noted, the occurrence of catastrophic spring floods, is a consequence of the implementation of a complex chain of causation. For their characteristics are important indicators such as the time interval between the start date of snow melting (or the transition of air temperature through $0^{\circ} \mathrm{C}$ ) and the start date of the flood, periods of rise and fall times of the snowmelt flood wave, spatial differences in the onset of flood phases within a single basin, etc.

At this stage, such indicators were determined selectively, and only for some years on the basis of a joint analysis of complex hydrological graphs for the March-May periods, which were created for r. Esil - Turgenevka (upper reaches) and Petropavlovsk (lower reaches). For example, such graphs are given below, according to 2013 data (in accordance with Figures 5, 6).

From the presented graphs, it turns out that in 2013, the flood on the upper post began on March 30th, 1-2 days after the air temperature passed through $0^{\circ} \mathrm{C}$. The increase in the flood wave lasted 12-13 days, its intense decline had a duration of 14-15 days, and later the general decline - about 20 more days. Precipitation had no visible effect on the runoff.

At the hydrological post of the Petropavlovsk city, located in the northern part of the basin, the snow-melt flood began more than 2 weeks later - on April 14th, 10-12 days after the transition of air temperature through $0^{\circ} \mathrm{C}$. Rising snow-melt flood waves here lasted 11-12 days, and its decline - more than one month. Precipitation here also had no visible effect on runoff.

The differences in the regime of water content on the same river at different posts, even within
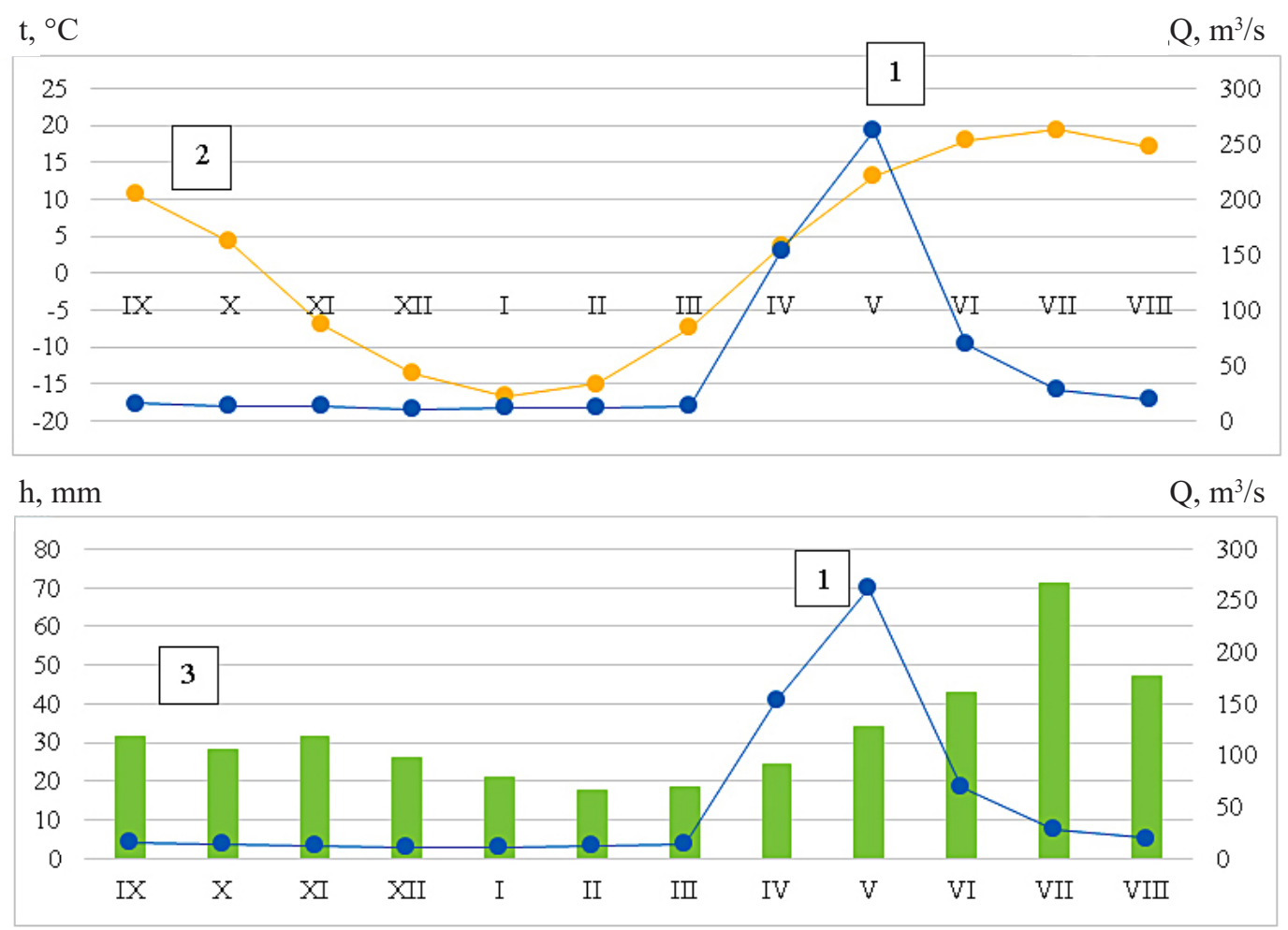

Figure 3. Multi-year (1992-2011) averages: (1) water discharge along the river Esil - h/p Petropavlovsk; $(2,3)$ air temperature and precipitation in the MS Petropavlovsk 
1)

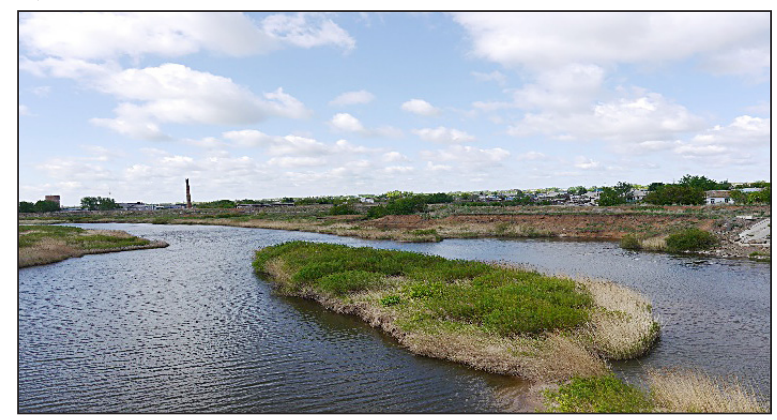

3)

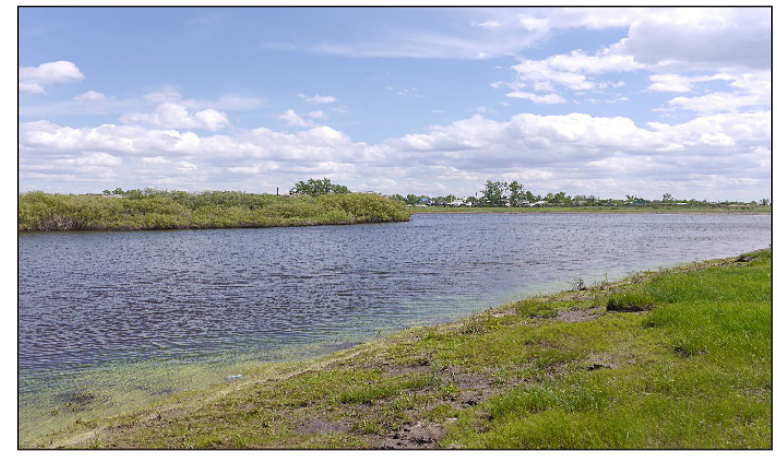

5)

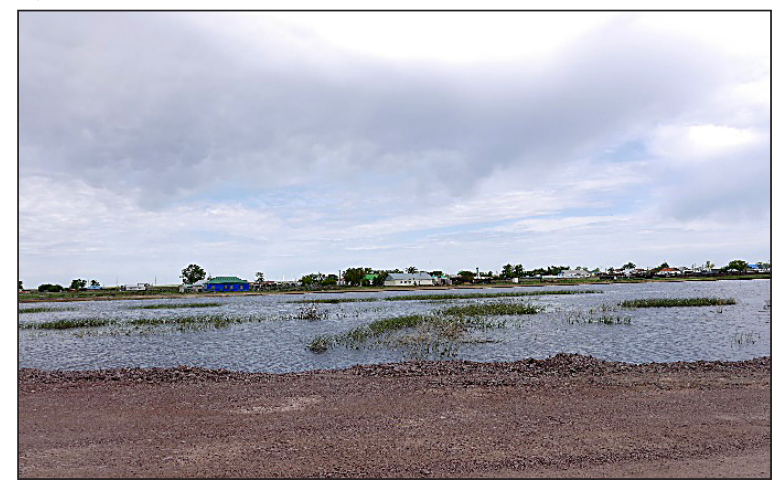

7)

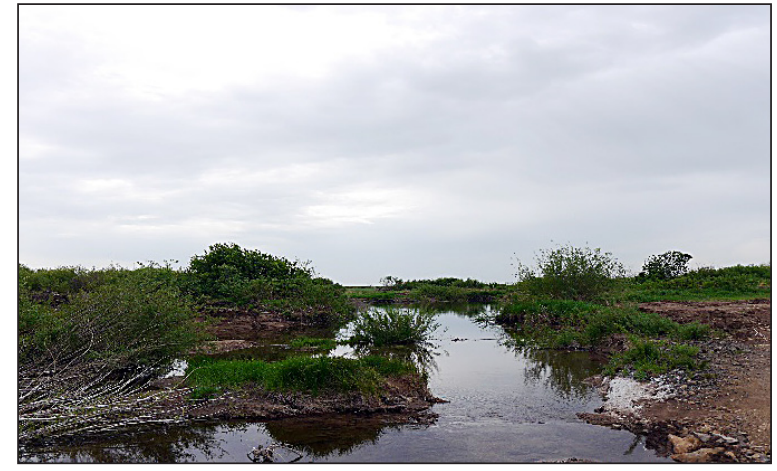

2)

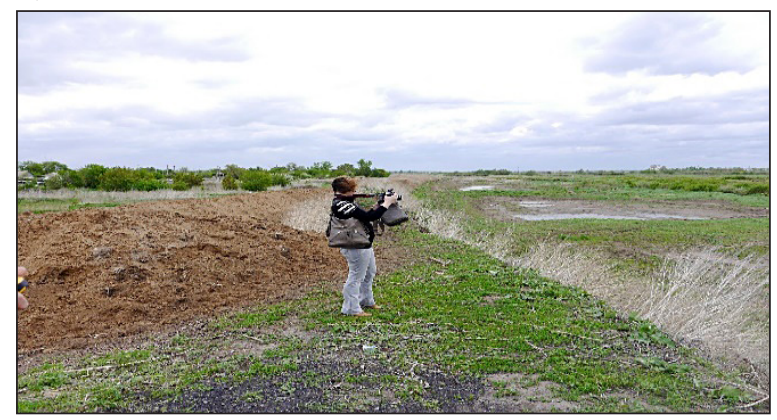

4)

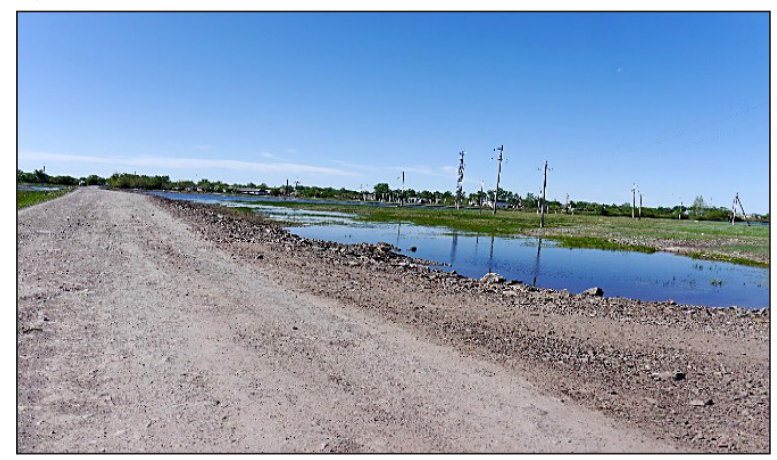

6)

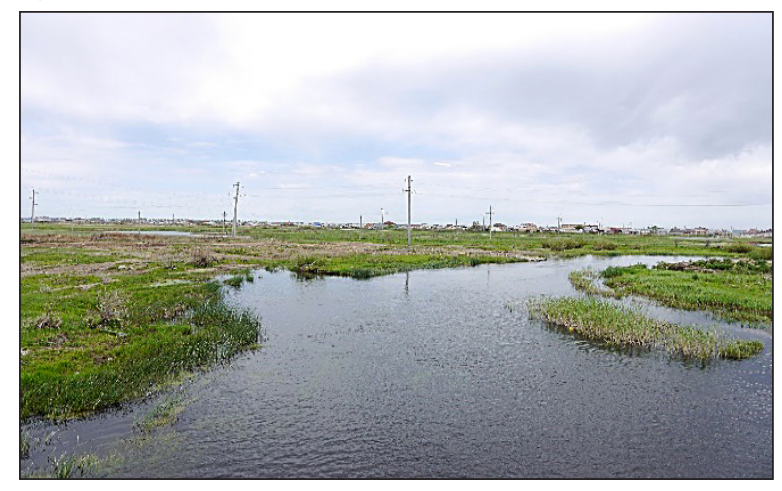

8)

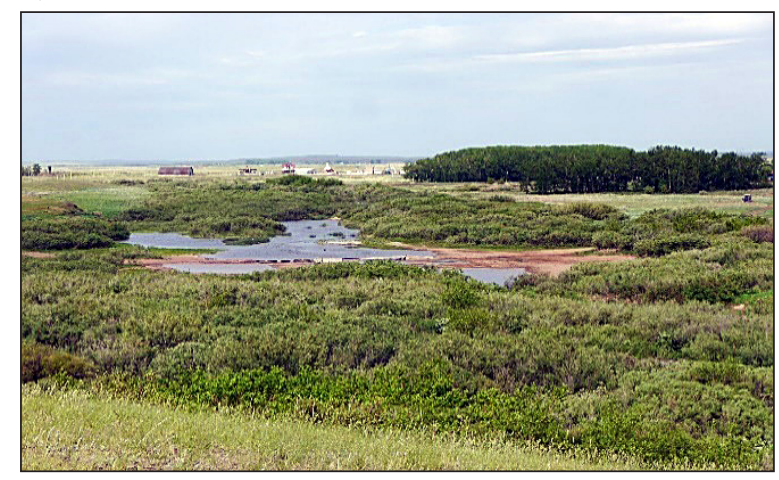

Figure 4. Esil river basin (photo by P.A. Plekhanov: May-June 2018): 1 - Zhabay river above the Atbasar city; 2 - a floodplain of the mouth of the Zhabay river; 3 - the floodplain of the Esil river near the Timashevka v.; 4 - the floodplain and a dead arm of river of Kalkutan river near the Old Koluton v.; 5 - the Esil river near the Akmeshit v; 6 - the Esil river near the Talapker v.; 7 - left channel of the Esil river, overgrown with bushes, above the Nur-Sultan (Astana) city; 8 - Esil river near the Kreschenovka v. (upper reaches): bulkhead and brushwood in the floodplain of the river). 
$\mathrm{Q}, \mathrm{m}^{3} / \mathrm{s}$

t, ${ }^{\circ} \mathrm{C}$

120

100

100
80

60

60
40
20

20

0

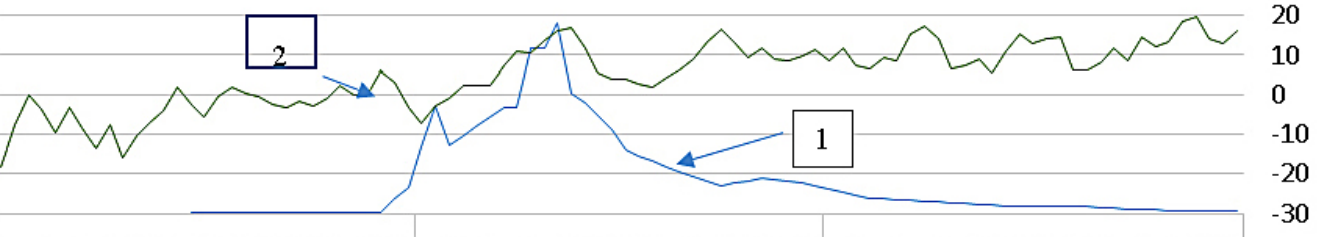

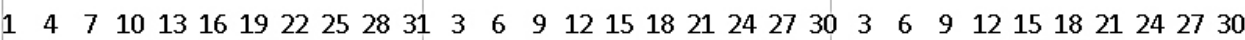

III

IV

$\mathrm{V}$

$\mathrm{Q}, \mathrm{m}^{3} / \mathrm{s}$

h, mm

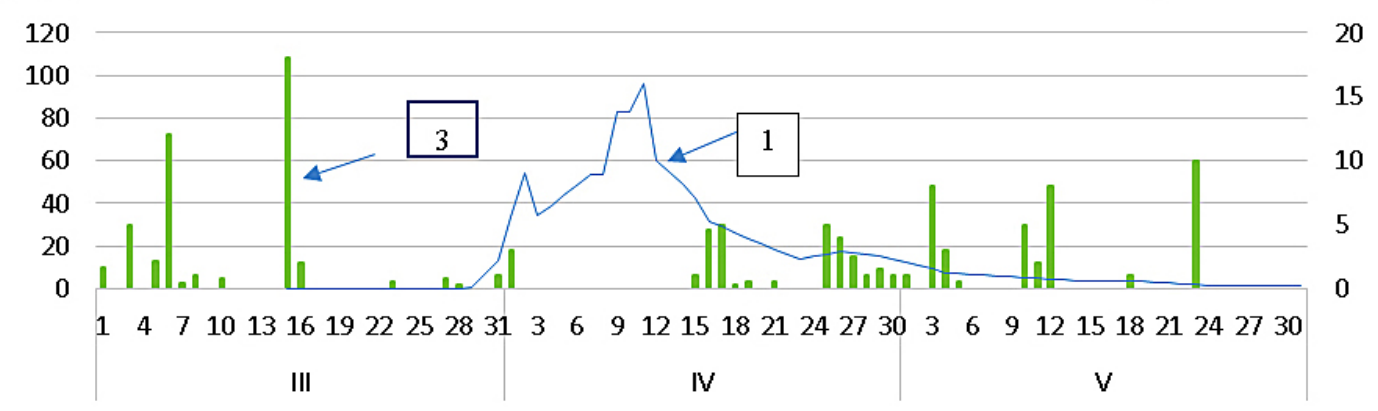

Figure 5. The course of average daily water discharge flow on the Esil River - the h/p Turgenevka (1), average daily air temperatures (2), and daily precipitation amounts (3) by the m/s Astana in March-May 2013

$\mathrm{Q}, \mathrm{m}^{3} / \mathrm{s}$ $\mathrm{t},{ }^{\circ} \mathrm{C}$

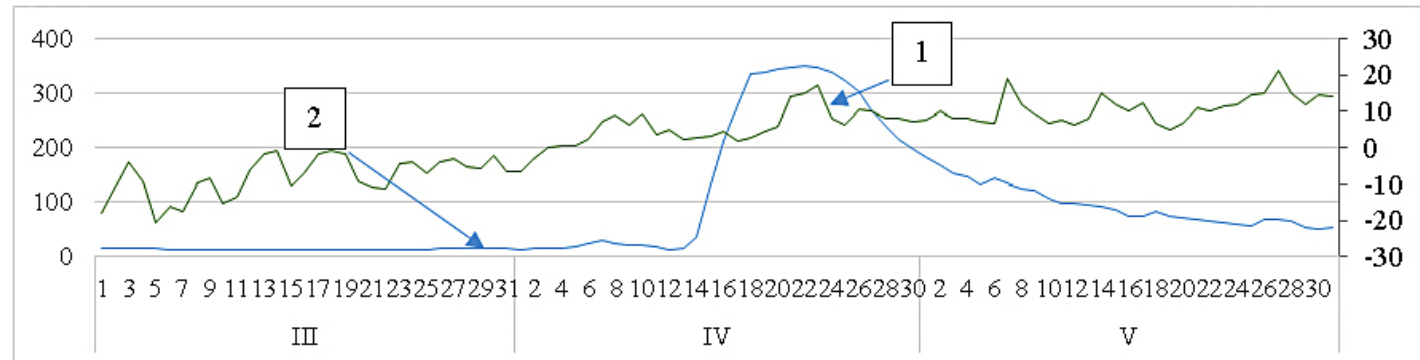

$\mathrm{Q}, \mathrm{m}^{3} / \mathrm{s}$

h, $\mathrm{mm}$

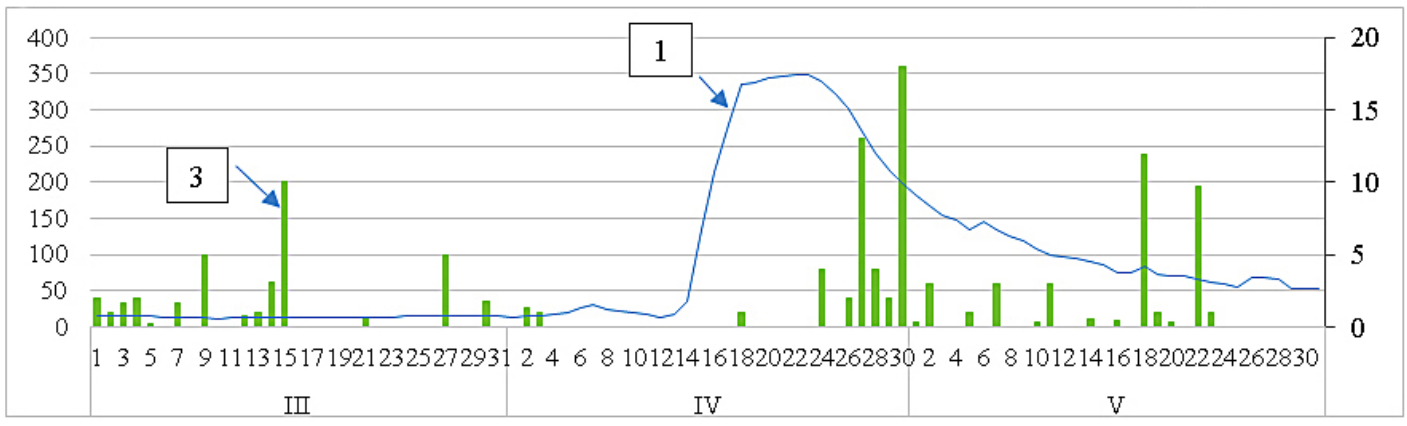

Figure 6. The course of average daily water discharge flow on the Esil River - the h/p Petropavlovsk c. (1), average daily air temperatures (2), and daily precipitation amounts (3) by m/s Petropavlovsk c. in March-May 2013

the same year of observation, certainly have their own explanations and must be supported by the corresponding full-scale surveys of specific areas.

Such generalizations about the objects of interest will be of great importance for establishing patterns of catastrophic floods. In order to study the long-term water regime in the Esil river basin, long-term difference integral flow curves were also constructed and analyzed along the Turgenevka h/p (upper reaches) and the Petropavlovsk $\mathrm{h} / \mathrm{p}$ (lower reaches) (according to Figures 7 and 8 ). 


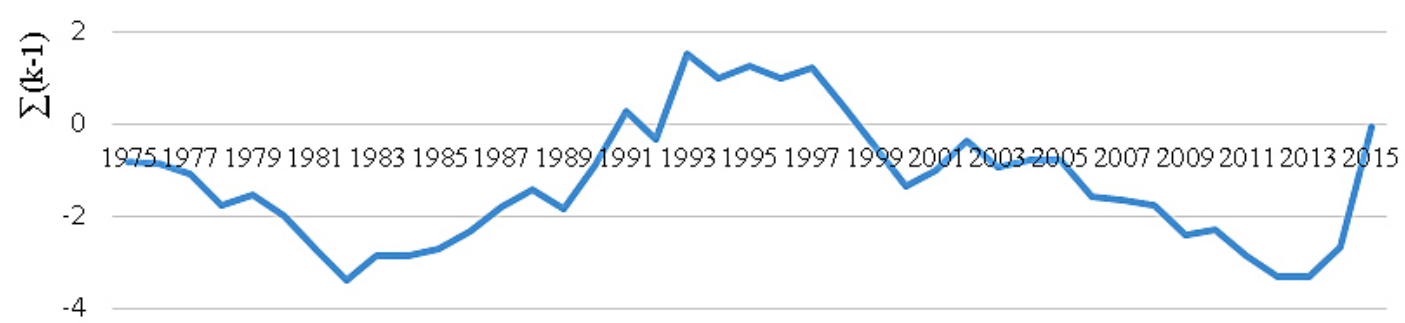

Years

Figure 7. Residual integral curve for the 1975-2015 the r. Esil - v.Turgenevka

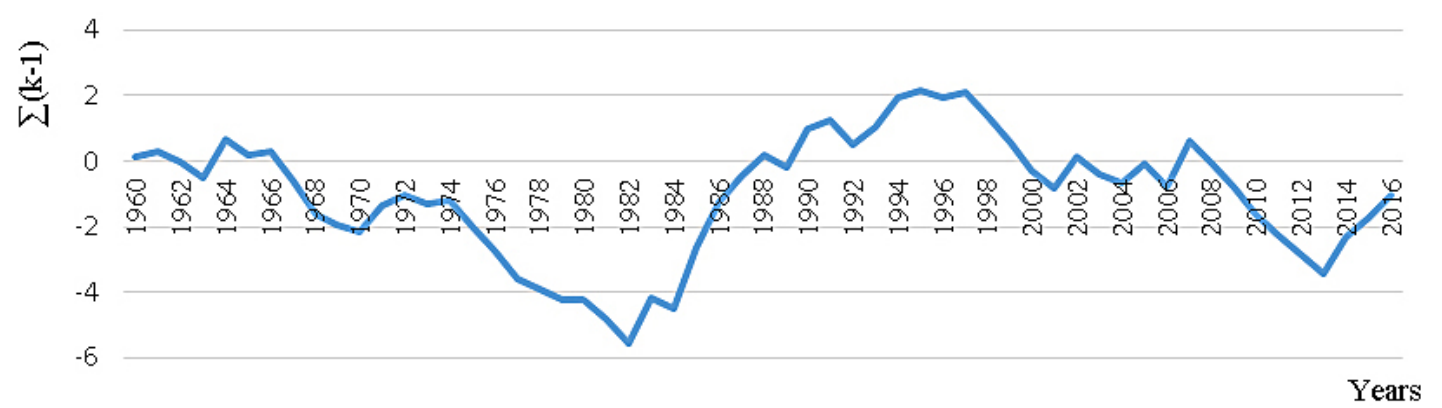

Figure 8. Residual integral curve for the 1960-2016 the r. Esil - c. Petropavlovsk

The analysis of the presented curves shows that the change in water content at both posts, i.e. in the upper and lower reaches of the Esil river occurs almost synchronously. For the high-water period for the entire basin, it is possible to accept the period from 1982 to 1997 (16 years), and for the low-water period - from 1998 to 2013, also 16 years). In general, the calculation period for determining the norms of flow parameters for the r. Esil should determine the period of a full water cycle in the amount of 32 years - from 1982 to 2013.

There is reason to believe that the regular high-water period began in 2014 in the Esil river basin, with which, perhaps, the intensification of inundation and floods in the Esil river basin in 2015-2017 is connected.

\section{CONCLUSION}

In the Esil WMB for the period from 1940 to the present, 41 occurrences of inundation of the area (including floods) were documented in 30 annual periods, including 20 annual periods of inundation noted in the years with high water content and in 10 in the years with low water content. This means that apparently only two-thirds of floods occurred due to increased water content.

Various "typical" scenarios for the formation of dangerous and catastrophic spring floods (floods) were identified. The periods of passage of snowmelt floods (spring floods) and other regularities of the intra-annual water regime in the Esil river basin were determined. For the high-water period for the entire Esil basin, the period from 1982 to 1997 (16 years) can be assumed, and for the lowwater period - the period from 1998 to 2013 (also 16 years), for the settlement period - 1982-2013. Obviously, since 2014, the next high-water period has begun in the Esil river basin.

The analysis of the flood control problem in the Esil River Basin showed that, there are still many important scientific and practical topics in solving this issue that require fundamental study: - study of the patterns of occurrence, functioning and harmful effects of inundation zones and floods on the population, economic objects and the environment;

- the study and monitoring of physical processes for the formation of spring flood flow in the catchment areas and in the river bed network of rivers under natural conditions;

- analysis and assessment of the representativeness of the existing network of hydrometeorological observations in the region and the development of proposals for its quantitative growth and qualitative development;

- improvement and development of new methods for creating digital maps of hazards and risks of extreme hydrological phenomena based on modern GIS technologies, etc. 


\section{Acknowledgement}

The article was prepared by the Institute of Geography LLP within the framework of the grant project of the MES RK № AR05135407 "Dangerous Hydrological Phenomena (floods) Control in the Esil basin (Akmola and North Kazakhstan provinces) in Changing Climate".

\section{REFERENCES}

1. Resources of river flow of Kazakhstan. 2012. Book 1. Renewable water resources of surface waters of Western, Northern, Central and Eastern Kazakhstan. Almaty.

2. Decree of the Government of the Republic of Kazakhstan "On the concept of prevention and liquidation of natural and man-made emergency situations and improvement of the state management system in this area". 2005. No. 1154.

3. Plekhanov, P.A., Rajushkin, B.V. 2011. Problems of safety of ponds and reservoirs in Kazakhstan. Materials of the Ural International Ecological Congress "Environmental safety of industrial regions". Ekaterinburg, Perm, 103-107.

4. Plan of preparedness of the Republic of Kazakhstan for natural emergencies. 2015. Ministry of Internal Affairs (CES) of RK. UNDP. Astana.

5. Kusainov, A.B. 2015. Analysis and risk assessment of hydrological hazards in the territory of the Karaganda region. Problems of ensuring safety in the aftermath of emergency situations. Vol. 1, 39-42.

6. Warning of an emergency situation during the spring flood period. 2012. Methodical manual. Kokshetau, p. 68.

7. National Flood Policies and Programs in Review. 2007. The Association of State Floodplain Managers, p. 102.

8. Shalikovsky, A.V. 2009. Analysis of international experience and flood risk management in the Rus- sian Federation. Water Industry of Russia: problems, technologies, management, 5, 18-34.

9. Directive 2007/60/EC. 2007. On the assessment and management of flood risks. European Parliament.

10. Connelly, A., Gabalda, V., Garvin, S., O'Hare, P., White, I. 2015. Testing innovative technologies to manage flood risk. Proceedings of the Institution of Civil Engineers Water Management, 68(2), 66-73.

11. Harvey, H., Hall, J., Manning, L. 2014. Computing flood risk in areas protected by flood defenses. Proceedings of the Institution of Civil Engineers Water Management, 167(1), pp. 38-50.

12. Uldashev, K.A. 2010. Flood control: World Experience Review. Information collection, p. 68.

13. Xu, Y., Du, J., Zhang, L., Ge, X., Peng, B. 2002. Research on system of flood disaster control and reduction supported by gis in medium and small basins. Chinese Geographical Science, 12(1), 3034. https://doi.org/10.1007/s11769-002-0067-z

14. Singh, O., Kumar, M. 2017. Flood occurrences, damages, and management challenges in India: a geographical perspective. Arabian Journal of Geosciences, 10(5), 102. https://doi.org/10.1007/ s12517-017-2895-2

15. Sardou, M., Maouche, S., Sabeur, B., Missoum, H. 2018. The November 26 and 27, 1927 devastating flood event (NW Algeria): characterization and reconstruction using historical data. Arabian Journal of Geosciences, 11(10), 229. https://doi. org/10.1007/s12517-018-3590-7

16. National Atlas of the Republic of Kazakhstan. 2010. Volume 1: Natural conditions and resources. Almaty, p. 150.

17. Plekhanov, P. A., Schoenberger, I.V., Medeu, N.N. 2018. Influence of underlying surface conditions on the formation of inundation and floods in the Esil basin. Questions of geography and geo-ecology, 3, 79-93.

18. Plekhanov, P.A., Medeu, N.N. 2019. Hydrological risks and their prevention in Kazakhstan. International Journal of Hydrology, 3(1), 3-4. 